\section{Soil Erosion and its Control}

By Prof. Q. C. Ayres. (McGraw-Hill Publications in Agricultural Engineering.) Pp. xi +365 . (New York and London: McGraw-Hill Book Co., Inc., 1936.) $21 s$.

ONE of the effects of the recent world depression has been to focus attention on problems of soil erosion. This has been the case particularly in the United States of America. The preceding years of high prices had led to a rapid expansion of mechanized farming, thereby reducing the man-power required to farm arable land. So long as prices ruled high, little notice was taken of the diminishing returns obtained from such expansive and continuous cropping, but as soon as the bottom fell out of the market, farmers discovered, almost overnight, that they could no longer carry on.

It was soon made clear that this was largely due to soil erosion and that the damage thus caused was increasing at an alarming rate. Whereas in 1910 it was estimated that ten million acres of farm land were ruined and abandoned, this figure had increased by 1935 to between thirty-five and fifty million acres. For years previously that "tireless little band of erosion technicians" to whom this book is dedicated, had been as a voice crying in the wilderness, and it required the effects of the depression forcibly to bring the position to the notice of the administration, which lost no time in forming this band of workers into the nucleus of a Soil Conservation Service. This Service, besides continuing research, was able to find employment for large numbers of farm workers and other unemployed in an endeavour to control soil erosion.

Since the initiation of this Service, much has been published in the form of bulletins, leaflets, etc., on soil erosion and its control. The author of the present work has collected and arranged this information under suitable headings, and the diagrams, tables, charts and numerous illustrations add much to the value of the text. Though based entirely on American experience and American farming conditions, the book should prove of value to those in other lands where somewhat similar problems and circumstances prevail.

\section{Revisiting my Pygmy Hosts}

By Paul Schebesta. Translated from the German by Gerald Griffin. Pp. $288+31$ plates. (London : Hutchinson and Co. (Publishers), Ltd., 1936.) 18s. net. AfTER two visits to the pygmies of the Congo in 1929 and 1930, Dr. Schebesta found himself constrained to pay them a third visit to obtain supplementary data. On this occasion his objective was in the area of Lake Albert and his hosts the Bambuti, as they call themselves. He has thus completed the tour of both the eastern and the western pygmies.

In this story of his sojourn among the little people of the forest, the author has purposely omitted any formal account of organization and culture where it does not differ from that described in his earlier work. Here again negroes and pygmies live in a relation in which each supplies something lacking in the economy of the other. The negroes need meat and the pygmy hunter supplies it: in turn, the pygmy needs bananas and vegetable produce, which is obtained from the negro gardens lacking in the pygmy culture.

Dr. Schebesta's lively picture of his relations with his pygmy people affords his readers an opportunity of appreciating their mentality. He has also taken full advantage of his informal method of description to demonstrate the actual working of their social and cultural organization and their magico-religious beliefs. The author is more than ever convinced that the culture of the pygmy is of purely forest origin, and that they are its aboriginal inhabitants.

\section{Exercices d'analyse}

Par Prof. Gaston Julia. Rédigés par Dr. Georges Bourion. Tome 4: Équations aux dérivées partielles du premier ordre. Pp. v+230. (Paris: GauthierVillars, 1935.) 60 francs.

THIS is the author's fourth volume of exercises in analysis. It is devoted mainly to partial differential equations of the first order, and consists of a discussion of some 55 problems taken from examination papers set at the Sorbonne for the Certificate in Calculus and from Part II of Édouard Goursat's "Course in Mathematical Analysis". The questions selected range from total differential equations to be solved by Bertrand's method, to simultaneous systems and problems in geometry involving partial equations. The solutions are not only complete, but also are characterized by their clarity and elegance. In nine cases, alternative methods, geometrical and analytical, are considered, whilst problem 53 is provided with three solutions. Relevant extensions, particular cases and applications are also indicated wherever possible.

To teachers and students of differential equations, this book should be extremely valuable.

$$
\text { F. G. W. B. }
$$

\section{A Marriage Manual :}

a Practical Guide-Book to Sex and Marriage. By Dr. Hannah M. Stone and Dr. Abraham Stone. English edition edited, and with an Introduction by, Michael Fielding. Pp. 352. (London : Victor Gollancz, Ltd., in conjunction with John Lane, The Bodley Head, Ltd., 1936.) $7 s .6 d$.

The admirable little work by Dr. Hannah M. Stone, medical director of the Birth Control Clinical Research Bureau of New York and Marriage Consultation Centre, and Dr. Abraham Stone, surgeon to the Sydenham Hospital and director of the Marriage Consultation Centre, is written in the form of imaginary conversations between a physician and a young couple about to be married. The subjects on which the pair seek enlightenment are fitness for marriage from the psychological, sexual and eugenic points of view, the anatomy and physiology of the sexual organs, fertility and sterility, prevention of conception, venereal diseases, the art of marriage including the technique of coitus, psychical and somatic incompatibilities and health in marriage. A bibliography of recent English and American literature is appended. 